\title{
Born Global Firm Internationalisation: The Influence of Industry Factors
}

\author{
Murray Taylor \\ Macquarie University \\ E-Mail: murray.taylor@mq.edu.au \\ Robert Jack \\ Macquarie University \\ E-Mail: rob.jack@mq.edu.au
}

\begin{abstract}
The established literature on born global firms has tended to overlook the significance of industry factors on born global firms' internationalisation processes. This paper explores recent conceptualisations of the early internationalisation processes of born global firms and their drivers within an industry context to determine how and why industry characteristics impact the internationalisation of born global firms. Drawing on the born global literature, this study adopts an exploratory, qualitative approach. The results from a multiple case study analysis of four Australiabased born global firms suggest that industry characteristics are a critical factor influencing each firm's internationalisation decisions. The key findings include high levels of global integration motivating firms to internationalise, high levels of local competition driving the choice of international markets to improve the firm's position in its domestic market, and the choice of entry mode being determined by industry trends.
\end{abstract}

Keywords: Born Global, Internationalisation, Industry Factors, Market Size, Choice of Markets, Entry Mode

\section{INTRODUCTION}

Since McKinsey \& Company (1993) originally explored the concept of born global firms, significant research has been undertaken to explore this form of internationalisation. Such research has revealed that born global firms are becoming increasingly widespread, particularly within niche, technology-driven markets (Chetty \& Campbell-Hunt, 2004; Nummela et al., 2014). A firm's industry has been found to 
be a major factor influencing its internationalisation strategy (Andersson, 2004; Andersson \& Wictor, 2003; Aspelund, Madsen \& Moen, 2007; Thai \& Chong, 2008). Industry factors have been identified from a variety of studies within the born global literature and include the internationalisation of the industry (Fernhaber, McDougall \& Oviatt, 2007), its international and domestic competitiveness (Evangelista, 2005), the stage of industry evolution (Fernhaber et al., 2007), the size of the domestic market (Johnson, 2004), and the homogeneity of international markets (Thai \& Chong, 2008).

Despite their identification and purported significance, the application of industry-related factors to born global firm internationalisation is rare (Rialp, Rialp \& Knight, 2005). Therefore, this paper aims to address the influence of industry factors on the internationalisation of born global firms. By undertaking a multiple case study analysis of four Australian born global firms from different industry backgrounds, the current research seeks to contribute to the born global internationalisation literature by addressing the following research question: How and why do industry characteristics impact the internationalisation of born global firms? The purpose of this paper is to identify the industry factors relevant to born global firms and then determine how they impact key internationalisation decisions-namely, the speed of their internationalisation, their choice of foreign markets, and their entry mode. Adopting this framework aims to reduce the differences between born global firms originating from diverse industries while also providing a broad perspective to study specific industry factors.

This paper is structured as follows: The extant literature relating to born global firm internationalisation and industry factors is reviewed. An overview of the methodology is provided, and an analysis of the results is presented. After discussing the results, suggestions for future research directions are offered. The paper concludes with an overview of the managerial implications and the limitations of the current research.

\section{BACKGROUND}

Currently, few studies have attempted to address the influence of a firm's industry on born global internationalisation, despite calls in the literature to do so (Aspelund et al., 2007; Fernhaber et al., 2007). Academic inquiry into born global firms has been limited to internal and organisational factors to better explain their internationalisation processes (Dib, da Rocha \& da Silva, 2010; Rialp-Criado, GalvanSanchez \& Suarez-Ortega, 2010; Taylor \& Jack, 2013). This has led to an increased interest in the linking of born global firms to international entrepreneurship, network 
theory, and learning effects (Cavusgil \& Knight, 2015; Gabrielsson et al., 2008; Hennart, 2014; Kalinic \& Forza, 2012; Kuivalainen, Sundqvist \& Servais, 2007; Sepulveda \& Gabrielsson, 2013). Aspelund et al. (2007), in their review of more than a decade's worth of born global research, suggested that, for new and viable models of firm internationalisation, a holistic perspective is required where other influences, such as industry factors, are included.

\section{SPEED OF INTERNATIONALISATION, CHOICE OF MARKETS, AND ENTRY MODE}

The pace of firm internationalisation has been a fundamental component of born global internationalisation and has been linked to improvements in transportation technologies, communication, changes in production, and the increased knowledge of human capital (Dib et al., 2010). Research has suggested that the size of the domestic market (Evangelista, 2005; Dib et al., 2010), the experiences and abilities of the entrepreneur (Lopez, Kundu \& Ciravegna, 2009; Oviatt \& McDougall, 2005), the commitment of management (Freeman \& Cavusgil, 2007), and industry structure (Andersson \& Wictor, 2003; Fernhaber et al., 2007) all have an impact on the speed of internationalisation of born global firms.

According to several authors (Andersen, 1993, 1997; Gallego et al., 2009), the fundamental strategic decisions in connection with a firm's internationalisation are associated with market selection and the choice of entry mode. Traditionally, internationalising firms choose an internationalisation pathway so that they can gain market knowledge while minimising the risks associated with internationalisation (Knight \& Cavusgil, 1996). Born global firms challenge this by entering multiple markets regardless of cultural or geographical proximity (Cavusgil \& Knight, 2015). Born global firms' market selection strategy was particularly emphasised in early born global research as researchers aimed to highlight an inconsistency between process models of internationalisation and the internationalisation of born global firms (Madsen \& Servais, 1997; Oviatt \& McDougall, 2005).

Entry mode is seen as a crucial factor in the internationalisation of traditional paths of internationalisation. However, there has been scant analysis within the born global literature regarding the mode of entry for early internationalising firms (Hashai, 2011). Born global firms' mode of entry has likely been neglected because exporting is assumed to be the initial mode of foreign market entry for the majority of firms that rapidly internationalise (Cavusgil \& Knight, 2015). Rialp et al. (2005) note that born global firms are more likely to export; consequently, studies have focused on this entry mode. Research further highlights that born global firms are unlikely to 
undertake foreign direct investment (FDI) because of the additional risk often associated with FDI (Kuivailenen et al., 2007; Rialp et al., 2005). The entry mode of born global firms is not a definitional stipulation; however, it remains significant to their internationalisation process (Gallego et al., 2009; Hashai, 2011; Kuivalainen et al., 2007; Melén \& Nordman, 2009). As the entry mode for born global firms is largely overlooked within the literature, it is important that it be emphasised as a major strategic decision in born global firms' internationalisation (Hashai, 2011; Knight \& Cavusgil, 2004).

In summary, a number of common factors within the literature have helped identify the early strategic behaviour of born global firms. These factors are often categorised into the speed of internationalisation (Oviatt \& McDougall, 2005; Casillas $\&$ Acedo, 2013), their choice of markets (Hashai, 2011), and the form of international entry mode (Melén \& Nordman, 2009).

\section{INDUSTRY FACTORS AND BORN GLOBAL FIRMS}

The term industry is frequently used to categorise, or group, individual companies based on common characteristics related to types of products, production technology, or market attributes (Boter \& Holmquist, 1996). By adopting a narrow industry focus, industry factors are more commonly associated with the increase in the number of born global firms reported rather than accounting for their strategic decision making. Despite suggestions that industry factors may provide an advantage in rapid internationalisation (Laanti, Gabrielsson \& Gabrielsson, 2007), limited empirical support exists for any associations between industry factors and the extent of a born global firm's internationalisation. In their review of environmental influences, Aspelund et al. (2007) outlined that the influence of industry factors in the born global literature is relevant to industry structure characteristics and the size of the domestic market. This finding supports Johnson (2004), who found that some of the most salient external factors influencing a firm's internationalisation process include the international integration of the industry, international competitiveness, and a small domestic market. Although it has been shown that these industry factors influence the ability of firms to internationalise (Andersson \& Wictor, 2003; Autio, Sapienza \& Almeida, 2000; Bell, Crick \& Young, 2004; Fan \& Phan, 2007), little empirical support exists for conclusions about how they may influence the internationalisation of born global firms.

Fernhaber et al. (2007) identified 20 specific industry structure variables relevant to a rapidly internationalising firm context and suggested they would have a significant impact on internationalisation decisions. They specifically identified 
factors such as the global integration of the industry and the level of competition that a firm faces as key determinants. These factors are supported by other studies that found the level of internationalisation of the industry, the age of the industry, and the competitive nature of international industry to be among the most important factors of born global internationalisation (Andersson \& Wictor, 2003; Johnson, 2004; Thai \& Chong, 2008).

Within this study, the industry structure characteristics examined are those considered to be the most influential in previous research. For this reason, the level of local competition within the industry (Andersson \& Wictor, 2003; Aspelund et al., 2007; Fan \& Phan, 2007, Thai \& Chong, 2008), the level of global integration, and the level of international competition (Fernhaber et al., 2007; Hashai, 2011; Johnson, 2004; Thai \& Chong, 2008) are all seen to be influential industry structure characteristics in a born global firm's internationalisation process.

Figure 1 represents the conceptual framework. The framework aims to integrate the three dimensions of born global internationalisation: the speed of internationalisation, choice of markets, and choice of entry mode. The purpose of the framework is to conceptualise this study's aims - namely, to identify how and why industry factors influence born global internationalisation.

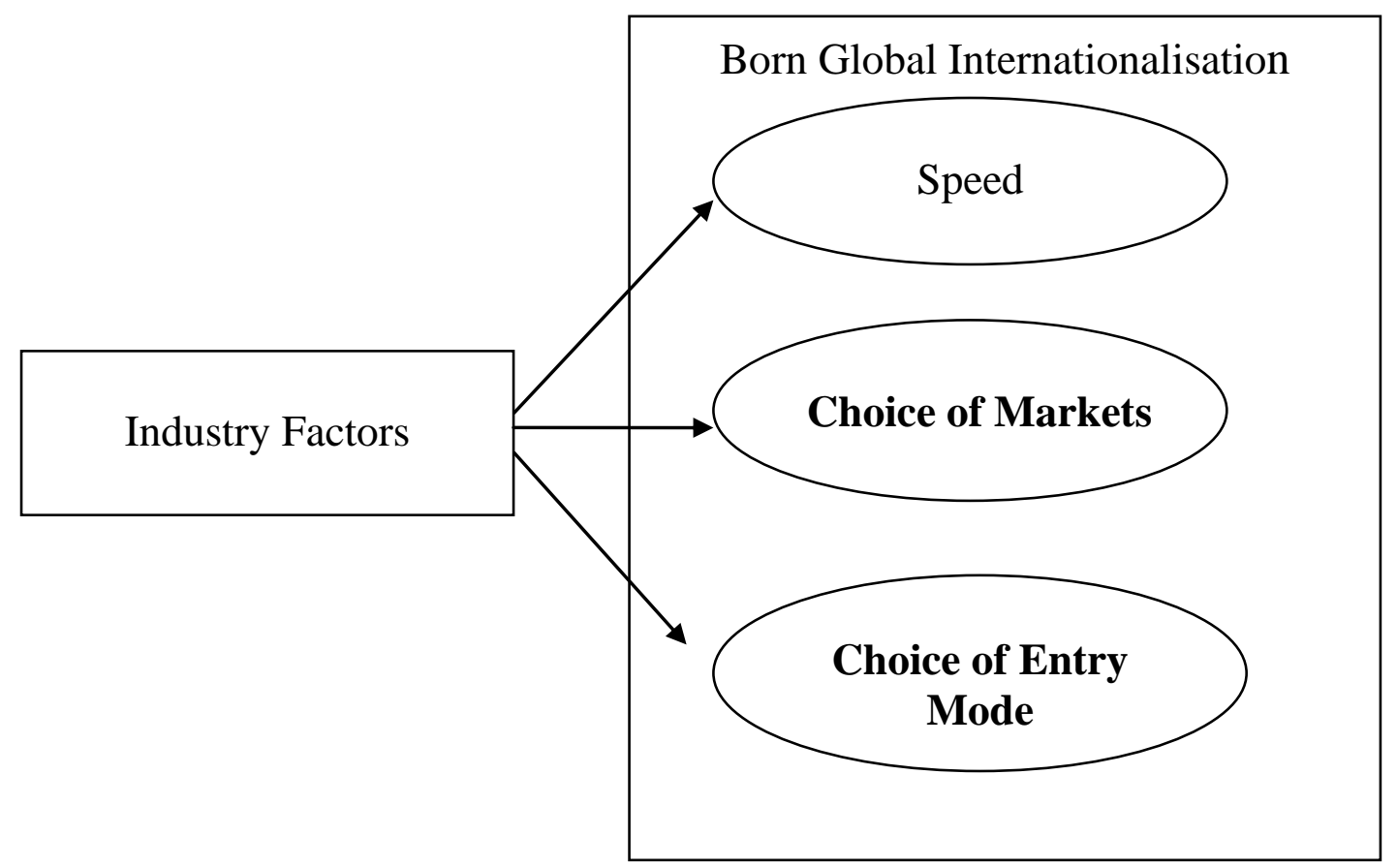

Figure 1 Conceptual Framework - Industry Factors and Born Global Internationalisation 


\section{METHODOLOGY}

This paper undertakes an exploratory, comparative case study of four Australiabased born global firms and examines the influence of industry factors on their internationalisation process. The complexity of the present study, with respect to the number of factors and their inter-relationship combined with a lack of prior in-depth research, suggests that case study methodology is the best alternative for achieving an in-depth understanding (Bamberger, 2000; Stake, 2013). The characteristics of case study research are appropriate when examining specific factors, such as industry factors, when examining a larger phenomenon, such as born global firms (Yin, 2009). The case study method used in this paper adheres to the approaches of Eisenhardt (1989) and Yin (2009).

As the research is exploratory, the need exists for an in-depth study of born global firms to aid in the enrichment and understanding of the phenomenon. Given that Australia's market is a relatively small and globally integrated economy, the growth of born global firms in the Australian market is common and has been the basis of previous academic research. The Australian sampling frame is further justified as it fulfils the need for an intensive study of firms so that the study can develop a theoretically rich understanding of the phenomenon.

Theoretical sampling was used to identify case firms consistent with the aim of the research (Miles \& Huberman, 2013). This was based on two criteria. The first criterion was that the organisations must adhere to what are considered to be the defining characteristics of born global firms. These characteristics are based on established literature and contain three attributes. First, the firm must have internationalised within three years of its inception. This speed of internationalisation was chosen as it is a common definitional boundary within the literature (Knight \& Cavusgil, 2004). Second, the firm must have entered into multiple (at least two) international markets within that timeframe. Finally, the firm must have a substantial share of total sales derived from foreign turnover (usually assessed as greater than $25 \%$ ). These characteristics are consistent with those used in previous studies (see Hashai, 2011; Knight \& Cavusgil, 2004; Kuivalainen, Saarenketo \& Puumalainen, 2012; Madsen, 2013; Moen \& Servais, 2002). The second criterion was that the firms must originate from different industries. With assistance from representative bodies such as the Australian Trade Commission (Austrade), the Export Council of Australia (ECA), and relevant industry associations, a list of potential case study firms from different sectors was initially identified.

Prospective firms were initially investigated and contacted by the researcher to determine if they meet the two previously detailed criteria and would be willing to 
participate in the study. Face-to-face interviews were the primary source of information and were undertaken with founders, partners, managing directors, and senior management. Interviews with each subject lasted between 70 and 140 minutes. Open-ended questions that focused on the internationalisation of the firm as well as the nature of its industry and its industry characteristics were asked. Following a semistructured interview process enabled the researcher to ask 'how' and 'why' questions which led to the accumulation of a rich data set. Table 1 details the key information about the respondents.

Table 1 Primary Data Collection Details

\begin{tabular}{lccc}
\hline Position of interviewee & Founder & $\begin{array}{l}\text { Duration of Each } \\
\text { Interview (Mins) }\end{array}$ & $\begin{array}{c}\text { Number of } \\
\text { Interviews }\end{array}$ \\
\hline & Firm 1 & & 2 \\
\hline Managing Director & Yes & 140 & 1 \\
\hline Director of Sales & Yes & 90 & 2 \\
\hline CEO & Firm 2 & 1 \\
\hline \multicolumn{5}{c}{ Yes } \\
\hline Chairman & Firm 3 & 80 & 1 \\
\hline \multicolumn{5}{c}{ Yes } \\
\hline Partner & Yes & 80 & 1 \\
\hline Chairman & Firm $\mathbf{4}$ & & 1 \\
\hline
\end{tabular}

Once interviews had been completed, the recordings were transcribed into separate Microsoft Word documents so that participants' responses could be analysed manually. The transcribed interviews were also entered into NVivo software. NVivo did not replace the researcher's role in analysing and interpreting the qualitative data. The specialised software's primary role was to assist in storing and managing the large quantities of data. NVivo was a particularly useful tool for linking data with emerging concepts and themes, exploring linkages within each case and across cases, and developing the overall conclusions of the study. To ensure the reliability of findings, a manual analysis was also utilised, which involved clustering the data to identify associations therein (Miles \& Huberman, 2013). This technique involved inductively forming categories through a detailed examination of the transcripts. As similarities between answers began to emerge, categories of responses were able to be determined, allowing the data to be classified and sorted accordingly. 
Next, a cross-case synthesis technique was employed. This aided in clustering relevant data and identifying any associations (Miles \& Huberman, 2013). Once data had been clustered, findings for each context were summarised in conceptually clustered matrices. Matrices were employed as an analytical tool to organise and analyse the data. The matrix technique promotes pattern matching and the effective categorisation of data (Miles \& Huberman, 2013). The research also adopted a general analytic approach that prioritises information through the development of data and the examination of similarities. The emergent findings are then tied to the extant literature, thereby enhancing internal validity and generalisability (Eisenhardt, 1989).

To supplement the primary data, secondary data were identified and used whenever possible. These data included background information available from company brochures, periodicals, newspaper articles, press releases, and any industry publications authored by the interviewees. Through the use of multiple secondary sources, the triangulation of data was achieved and assisted in cross-referencing data and correcting any misinformation. Finally, it avoided any interpretation errors as well as enhancing construct validity and ensuring a well-rounded analysis (Stake, 2013; Yin, 2009).

\section{FINDINGS AND DISCUSSION}

Table 2 summarises the findings of the research study by displaying the industry characteristics for each firm and their internationalisation motivations. Consistent with the established literature, the results revealed two key sets of industry factors: (i) level of global industry integration and international competition and (ii) level of local competition. The results also highlighted a third and emergent industry factor: global trends within an industry. The issues highlighted by Table 2 are discussed in greater detail next.

(i) Level of Global Integration and International Competition

The level of global integration of an industry is based on the extent, intensity, and degree of integration of relationships across borders within that industry (Madsen \& Servais, 1997). The global integration of the case study firms presented different challenges. Two firms (Firm 2 and Firm 4) internationalised to capture the foreign market. Both firms saw opportunities originate from the nature of the industry having a small number of dominant firms. Both firms had aspirations to fill this gap within their industry.

The findings also revealed that born global firms are not daunted by the challenges associated with internationalising within industries that have a small number of highly dominant firms. Both Firm 1 and Firm 3 wished to compete directly 
with their major competitors. In the case of Firm 1, it recognised that the industry had a small number of major firms and very little additional competition. Despite the firms' size and lack of resources, compared to its counterparts, the founders recognised that this was the best way to survive:

"We challenged the big firms and we competed against companies that were at least 10-20 times bigger than us. To be able to survive we had to do it quickly." (Firm 1, Founder)

Similarly, Firm 3 expanded into the market it perceived as being the most competitive in its industry (USA) so that it could compete directly with the largest competitors in the industry. Firm 1 and Firm 3 wished to gain a larger foothold in their industry.

Although these findings support extant literature, which suggests that highly competitive domestic industries encourage internationalisation (Chetty \& CampbellHunt, 2004), they also show an additional strategy for firms that operate within less highly concentrated industries. Firm 2 and Firm 4 considered their industries to be fragmented, with the vast majority of international competition being limited to regions with few global competitors. Both firms understood that, because there were very few firms that competed globally, there was an opportunity to become a global market leader. They internationalised quickly so that they could gain an advantage against current and future competitors. In the case of Firm 2, the firm saw it as an opportunity that could benefit the firm in its position overseas, but it recognised that it needed to be quick to gain such an advantage. The firm hoped to leverage its international position into additional markets as well as those in which it currently operated:

"It was definitely the lack of international competition which encouraged us to go overseas so quickly...nobody was actively out there trying to grow their business internationally which encouraged us to go overseas." (Firm 2, Founder)

These findings provide insights into conflicting perspectives on the influence of the level of global integration of an industry. Furthermore, the findings confirm that industries characterised by a small number of large competitors and which have a larger portion of the global market share are encouraged to internationalise. The findings also highlight an additional strategy for those firms operating in global markets with a larger number of small to medium-sized competitors. Thus, the following propositions are presented:

- P1: In industries with high levels of global integration and international competition, the pace of born global internationalisation is determined by the firm's need to survive rather than to meet entrepreneurial aspirations. 
- P2: In industries with low levels of global integration and international competition, the pace of born global internationalisation is determined by entrepreneurial aspirations rather than a need to survive.

Table 2 Industry Characteristics and Internationalization Motivations

\begin{tabular}{|c|c|c|c|c|}
\hline & Firm 1 & Firm 2 & Firm 3 & Firm 4 \\
\hline Industry & $\begin{array}{c}\text { Food } \\
\text { packaging }\end{array}$ & $\begin{array}{l}\text { Mobile } \\
\text { phone }\end{array}$ & Fashion & Consulting \\
\hline $\begin{array}{l}\text { (i) Level of global } \\
\text { integration and } \\
\text { international } \\
\text { competition }\end{array}$ & High & Low & High & Low \\
\hline $\begin{array}{l}\text { Impact on firm } \\
\text { internationalisation }\end{array}$ & $\begin{array}{l}\text { Speed - } \\
\text { need to } \\
\text { survive }\end{array}$ & $\begin{array}{l}\text { Speed }- \\
\text { opportunity to } \\
\text { capture } \\
\text { market }\end{array}$ & $\begin{array}{c}\underline{\text { Speed }}_{-}- \\
\text {need to survive }\end{array}$ & $\begin{array}{l}\underline{\text { Speed }-} \\
\text { opportunity to } \\
\text { capture market }\end{array}$ \\
\hline $\begin{array}{l}\text { (ii) Level of local } \\
\text { competition }\end{array}$ & Low & Low & High & High \\
\hline \multirow{2}{*}{$\begin{array}{l}\text { Impact on firm } \\
\text { internationalisation }\end{array}$} & $\begin{array}{l}\text { Speed }- \\
\text { industry was } \\
\text { too small to } \\
\text { sustain } \\
\text { business }\end{array}$ & $\begin{array}{c}\text { Speed }- \\
\text { industry was } \\
\text { too small to } \\
\text { sustain } \\
\text { business }\end{array}$ & $\begin{array}{c}\text { Speed - } \\
\text { Pressure to } \\
\text { internationalise } \\
\text { to gain further } \\
\text { customers }\end{array}$ & $\begin{array}{l}\text { Speed - } \\
\text { Pressure to } \\
\text { internationalise } \\
\text { to gain further } \\
\text { customers }\end{array}$ \\
\hline & $\begin{array}{c}\frac{\text { Choice of }}{\text { market }-} \\
\text { aimed for } \\
\text { most } \\
\text { opportunistic } \\
\text { market } \\
\end{array}$ & $\begin{array}{c}\frac{\text { Choice of }}{\text { market }-} \\
\text { aimed for } \\
\text { most } \\
\text { opportunistic } \\
\text { market }\end{array}$ & $\begin{array}{l}\frac{\text { Choice of }}{\text { market }-} \\
\text { Benefit to local } \\
\text { market by } \\
\text { entering } \\
\text { foreign market }\end{array}$ & $\begin{array}{l}\frac{\text { Choice of }}{\text { market }-} \\
\text { Benefit to local } \\
\text { market by } \\
\text { entering } \\
\text { foreign market }\end{array}$ \\
\hline $\begin{array}{l}\text { (iii) Global industry } \\
\text { trends }\end{array}$ & Existed & Didn't exist & $\begin{array}{l}\text { Founder was } \\
\text { well aware of } \\
\text { competitor } \\
\text { strategies }\end{array}$ & Didn't exist \\
\hline \multirow{2}{*}{$\begin{array}{l}\text { Impact on firm } \\
\text { internationalisation }\end{array}$} & $\begin{array}{c}\frac{\text { Choice of }}{\text { market }} \\
\text { - firm directly } \\
\text { competed } \\
\text { against } \\
\text { competitors }\end{array}$ & $\begin{array}{c}\frac{\text { Choice of }}{\text { market }} \\
\text { - firm chose } \\
\text { most suitable } \\
\text { markets }\end{array}$ & $\begin{array}{c}\frac{\text { Choice of }}{\text { market }} \\
\text { - firm directly } \\
\text { competed } \\
\text { against } \\
\text { competitors }\end{array}$ & $\begin{array}{c}\frac{\text { Choice of }}{\underline{\text { market }}} \\
\text { - firm chose } \\
\text { most suitable } \\
\text { markets }\end{array}$ \\
\hline & $\begin{array}{l}\text { Choice of } \\
\text { entry mode } \\
\text { Firm followed } \\
\text { competitors } \\
\text { entry mode } \\
\text { strategies }\end{array}$ & $\begin{array}{l}\text { Choice of } \\
\frac{\text { entry mode }}{\text { Firm chose }} \\
\text { most suitable } \\
\text { entry mode }\end{array}$ & $\begin{array}{l}\text { Choice of } \\
\text { entry mode } \\
\text { Firm followed } \\
\text { competitors } \\
\text { entry mode } \\
\text { strategies }\end{array}$ & $\begin{array}{l}\frac{\text { Choice of }}{\text { entry mode }}- \\
\text { Firm chose } \\
\text { most suitable } \\
\text { entry mode }\end{array}$ \\
\hline
\end{tabular}


(ii) Level of Local Competition

Studies that have focused on high technology industries have outlined that firms internationalise rapidly so that they can remain viable against larger, highly internationalised competitors (Fan \& Phan, 2007; Thai \& Chong, 2008). Two of the firms (Firm 3 and Firm 4) characterised the level of international competition within their home (local) market industry as 'high'. Firm 4 operates in a highly competitive, fragmented industry. The innovations they made to their product diverted enough from the industry standards so that they needed to 'educate' each market they entered. This took time as clients began to understand the value in their unique service offering. The founders recognised that their fragmented and highly competitive industry presented an opportunity both overseas as well as in their local market. As one of the founders of Firm 4 explained:

"Our industry is a cottage industry that is very competitive with many smaller players. That makes it difficult to stand out absolutely. But because of that we could go overseas to well-known markets and establish ourselves overseas so we become more attractive here [in the domestic market]." (Firm 4, Founder)

Evangelista (2005) found that, when the domestic market is hostile and highly competitive, firms may be forced to internationalise as an attempt to avoid intense or direct competition. Neither Firm 3 nor Firm 4 were trying to avoid local competition; they were trying to improve their position in the local market by internationalising prior to establishing local operations. As the founder of Firm 3 noted:

“Because it was a brand new product, I didn't have a product history, so local people did not want to take a gamble on it...Australia is a very competitive market, so I went to the US which is a big market and is even more competitive. I got an order immediately that was so big I almost fell off my seat. Then I came back to Australia, and because of that order, everyone wanted one." (Firm 3, Founder)

Previous studies have noted the importance of the competitive nature of the local industry. Both Thai and Chong (2008) and Johnson (2004) found it to be a contributing factor to the way in which born global firms internationalised. In his cross-cultural study of early internationalising firms, Johnson (2004) found the international and competitive nature of a firm's industry to be a strong factor for both UK and US born global firms. Based on the findings, the following propositions are presented:

- P3: A highly competitive local industry encourages born global internationalisation to improve the firm's position in the local market. 
- P4: A highly competitive local industry encourages born global internationalisation into large, well-known established markets.

(iii) Global industry trends

According to Bell et al. (2004), the market selection and entry strategies of born global firms are more likely to be influenced by relationships with clients and global industry trends, rather than by the geographic or 'psychological' proximity of overseas markets. They found that knowledge-intensive firms were influenced by global industry trends and were more likely to enter lead markets in their particular field. The findings revealed that global industry trends are an emergent finding with two of the case study firms (Firm 1 and Firm 3), acknowledging that they were aware of the global industry leader's internationalisation strategies and assessed this as a guide in their internationalisation decisions. When Firm 1 first internationalised, it competed against a small number of very large international firms within its industry. The firm chose to enter the UK market because other major competitors existed there; the firm chose their entry mode because that is how competitors had previously entered the market. As the founder of Firm 1 explained:

"The nature of the industry kind of created the plan and the outline of how we should do it. The nature of the industry itself was mainly appointing distributors and agents, which was the prevailing method. So that's what we did." (Firm 1, Founder)

Both Firm 1 and Firm 3 followed the internationalisation pathways of other firms in their industry. Both firms also recognised that their industry was highly internationalised.

Establishing a market position can be a high drain on resources when introducing products and services into new markets. Firms must dedicate time and financial resources to educate and inform the market about their products and services (Trudgen \& Freeman, 2014). In the case of Firm 2 and Firm 4, the firms' products were highly innovative and operated in a niche part of their industry, causing both firms to be cautious in how they introduced their products to new markets. Both firms operated in industries with low levels of global integration. In the case of Firm 2, the firm's product was mostly unknown. Although competitors existed, they were small, so the market did not fully understand the product:

"The market was a little bit there [when we internationalised], but we really created the market. No one really knew what [my product] was. I was constantly building awareness as to what the product was." (Firm 2, Founder) 
These findings emphasise that global industry trends are important when examining firms that rapidly internationalise. The findings highlighted different motivations for firms operating in industries with different industry characteristics. Therefore, the final set of propositions are:

- P5: Firms that operate in highly internationalised industries are more likely to follow global industry trends in their choice of markets and choice of entry mode.

- P6: Firms that operate in industries with low levels of global integration are less likely to follow global industry trends and more likely to choose markets and entry mode options that are more suitable to their own circumstances.

This paper has integrated the findings of born global internationalisation, examining the impact of industry characteristics derived from previous born global research (Aspelund et al., 2007; Casillas \& Acedo, 2013; Hashai, 2011; Kuivalainen et al., 2007; Madsen, 2013; Melen \& Nordman, 2009). It is proposed that the nature of an industry is highly influential on the internationalisation process of born global firms. This includes the three internationalisation dimensions that a born global firm follows: the speed of internationalisation, its choice of markets, and its mode of entry (see Figure 2).

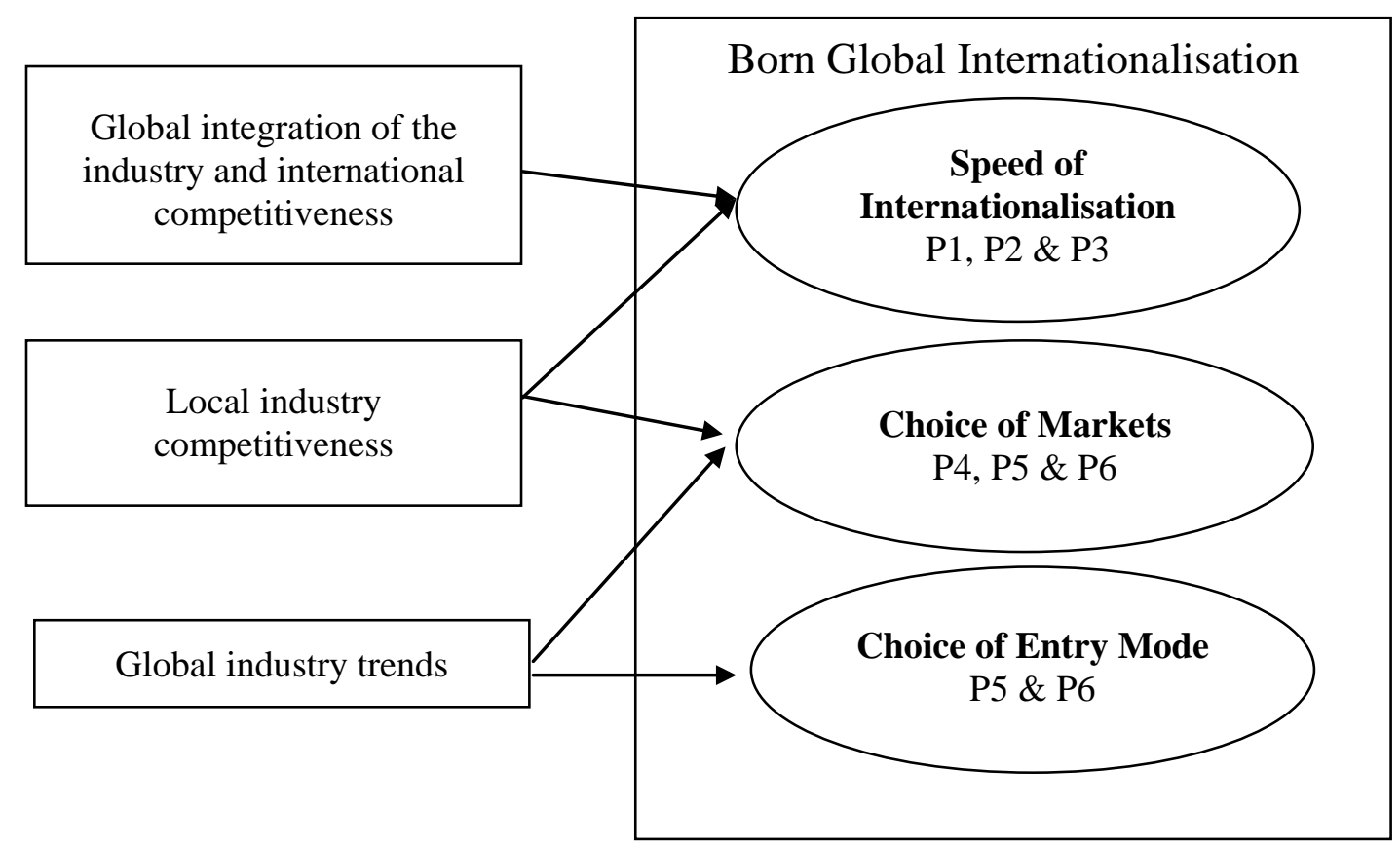

Figure 2 Impact of Industry Factors on Born Global Internationalisation 


\section{CONCLUSION}

This paper is one of the first to empirically explore the application of industry factors on born global firm internationalisation. This study drew upon the literature to contribute to this aim by providing theoretical and empirical insights into how industry characteristics influence the internationalisation of born global firms. This research built on recent efforts (e.g., Dib et al., 2010; Kalinic \& Forza, 2012; Kuivalainen et al., 2007; Laurell et al., 2013; Sepulveda \& Gabrielsson, 2013) to outline important elements of the born global process to examine the impact of industry factors in a way that acknowledges the unique characteristics of born global firms as well as the industries in which they operate. Furthermore, the unique internationalisation strategies of born global firms were also taken into consideration (Cavusgil \& Knight, 2015; Madsen, 2013) so as to identify the impact of industry factors across the internationalisation process.

The contributions to the literature from this study are four-fold. First, the findings show that the nature of the industry impacts the pace of internationalisation. Firms that originated in industries with high levels of international competition and high levels of global integration are motivated to internationalise to gain international customers to survive. These firms believe that, in their highly competitive industries, the founders' global aspirations were second to the pressure placed on the firms to compete globally so the firm may survive. Firms originating from industries that do not share the same competitive pressures, or the same level of global integration, align with previous born global research that emphasise the role of the founder and their global aspirations that primarily motivate the firm to internationalise.

Second, highly competitive local industries motivate firms to internationalise so that they may become more competitive in their home market. This impacts firms' choice of markets as these firms seek markets that will provide them with credibility in the home market. For this reason, they choose to enter large, well-known markets that contribute to their international exposure in the domestic market.

Third, the location and entry mode choices of born global firms highlight the importance of established industry leaders and global industry trends. In highly internationalised industries, firms are more likely to follow the internationalisation pathways of other leading firms, thereby allowing the firm to rely on previously successful strategies as well as compete directly with established competitors.

Finally, those firms operating in markets with low levels of global integration do not have the same opportunities to follow competitors' internationalisation pathways. Although, they compete against firms in specific markets, they do not have large dominant firms with which to directly compete. This may increase the perceived risk 
of internationalisation as these firms choose markets and entry modes that they consider to be most appropriate rather than following other firms' internationalisation pathways.

The findings have been integrated into several propositions that examine the impact of industry characteristics along three key born global internationalisation dimensions derived from previous born global research (Aspelund et al., 2007; Casillas \& Acedo, 2013; Hashai, 2011; Kuivalainen et al., 2007; Madsen, 2013; Melén \& Nordman, 2009).

\section{IMPLICATIONS AND LIMITATIONS}

The foregoing discussion indicates that the born global concept is a highly complex phenomenon. Since the growth of the born global literature, research has focused on internal factors for internationalisation and tended to overlook the importance of industry factors on firms' internationalisation processes. Based on the analysis contained in this study, it would be prudent for future researchers of born global internationalisation studies to incorporate industry factors into their models.

The value of this paper's approach extends to practitioners and policy-makers. Managers of firms in the midst of early development, particularly those that aim to rapidly and strategically internationalise, can benefit from the identification of factors found to influence early internationalisation. The influence of industry factors outlined in this paper offers a starting point for a firm's analysis of its internationalisation strategy. Managers who are more aware of industry influences will be better prepared to pursue flexible strategies enabling the firm to adapt to external influences.

Several limitations of the study also need to be noted. The current research examined four case studies. An extension of this research examining industry factors of born global firms from a quantitative perspective is warranted. This would help generalise and build on the current findings. Overall, the internationalisation of born global firms is influenced by multiple factors. The preliminary findings in this study suggest that industry factors may influence each other; thus, a more comprehensive assessment of these factors is required. 


\section{REFERENCES}

Andersen, O., (1993). On the internationalization process of firms: A critical analysis. Journal of International Business Studies, 24(2), 209-231. http://dx.doi.org/10.1057/palgrave.jibs.8490230

Andersen, O., (1997). Internationalization and market entry mode: a review of theories and conceptual frameworks. Management International Review, 37, 2742. http://www.jstor.org/stable/40228431

Andersson, S. (2004). Internationalization in different industrial contexts. Journal of Business $\quad$ Venturing, $19(6), \quad 851-875$. http://dx.doi.org/10.1016/j.jbusvent.2003.10.002

Andersson, S., \& Wictor, I., (2003). Innovative internationalisation in new firms: born globals-the Swedish case. Journal of International Entrepreneurship, 1(3), 249275. http://dx.doi.org/10.1023/A:1024110806241

Aspelund, A., Madsen, T. K., \& Moen, O., (2007). A review of the foundation, international marketing strategies, and performance of international new ventures. European Journal of Marketing, 41(11/12), 1423-1448. http://dx.doi.org/10.1108/03090560710821242

Autio, E., Sapienza, H. J., \& Almeida, J. G. (2000). Effects of age at entry, knowledge intensity, and imitability on international growth. Academy of management journal, 43(5), 909-924. http://dx.doi.org/10.2307/1556419

Bamberger, M. (Ed.). (2000). Integrating quantitative and qualitative research in development projects. World Bank Publications.

Bell, J., Crick, D., \& Young, S., (2004). Small Firm Internationalization and Business Strategy: An Exploratory Study of 'Knowledge-Intensive' and 'Traditional' Manufacturing Firms in the UK. International Small Business Journal, 22(1), 23. http://dx.doi.org/10.1177/0266242604039479

Boter, H., \& Holmquist, C., (1996). Industry characteristics and internationalization processes in small firms. Journal of Business Venturing, 11(6), 471-487. http://dx.doi.org/10.1016/S0883-9026(96)89166-X

Casillas, J. C. \& Acedo, F. J. (2013). Speed in the internationalization process of the firm. International Journal of Management Reviews, 15(1), 15-29. http://dx.doi.org/10.1111/j.1468-2370.2012.00331.x

Cavusgil, S. T. \& Knight, G. (2015). The born global firm: An entrepreneurial and capabilities perspective on early and rapid internationalization. Journal of International Business $\quad$ Studies, $\quad 46(1), \quad$ 3-16. http://dx.doi.org/10.1057/jibs.2014.62 
Chetty, S., \& Campbell-Hunt, C. (2004). A strategic approach to internationalization: a traditional versus a "born-global” approach. Journal of International Marketing, 12(1), 57-81. http://dx.doi.org/10.1509/jimk.12.1.57.25651

Dib, L. A., da Rocha, A., \& da Silva, J. F. (2010). The internationalization process of Brazilian software firms and the born global phenomenon: Examining firm, network, and entrepreneur variables. Journal of International Entrepreneurship, 8(3), 233-253. http://dx.doi.org/10.1007/s10843-010-0044-z

Eisenhardt, K. M. (1989). Building theories from case study research. Academy of Management Review, 14(4),

532-50. http://dx.doi.org/10.5465/AMR.1989.4308385

Evangelista, F. (2005). Qualitative insights into the international new venture creation process. Journal of International Entrepreneurship, 3(3), 179-198. http://dx.doi.org/10.1007/s10843-005-4204-5

Fan, T. \& Phan, P. (2007). International new ventures: revisiting the influences behind the 'born-global'firm. Journal of International Business Studies, 38(7), 11131131 .

Fernhaber, S. A., McDougall, P. P., \& Oviatt, B. M., (2007). Exploring the Role of Industry Structure in New Venture Internationalization. Entrepreneurship Theory and Practice, 31(4), 517-542. http://dx.doi.org/10.1111/j.15406520.2007.00186.x

Freeman, S., \& Cavusgil, S. T. (2007). Toward a Typology of Commitment States Among Managers of Born-Global Firms: A Study of Accelerated Internationalization. Journal of International Marketing, 15(4), 1-40. http://dx.doi.org/10.1509/jimk.15.4.1

Gabrielsson, M., Kirpalani, V. H. M., Dimitratos, P., Solberg, C. A., \& Zucchella, A. (2008). Born globals: Propositions to help advance the theory. International Business Review, 17(4), 385-401. http://dx.doi.org/10.1016/j.ibusrev.2008.02.015

Gallego, M. Á., Hidalgo, E. R., Acedo, F. J., Casillas, J. C., \& Moreno, A. M. (2009). The relationship between timing of entry into a foreign market, entry mode decision and market selection. Time \& Society, 18(2-3), 306-331. http://dx.doi.org/10.1177/0961463X09337843

Hashai, N. (2011). Sequencing the expansion of geographic scope and foreign operations by "born global" firms. Journal of International Business Studies, 42(8), 995-1015. http://dx.doi.org/10.1057/jibs.2011.31

Hennart, J. F. (2014). The accidental internationalists: a theory of born globals. Entrepreneurship Theory and Practice, 38(1), 117-135. http://dx.doi.org/10.1111/etap.12076 
Johnson, J. E., (2004). Factors influencing the early internationalization of high technology start-ups: US and UK evidence. Journal of International Entrepreneurship, 2(1), 139-154. http://dx.doi.org/10.1023/B:JIEN.0000026910.87323.4e

Kalinic, I. \& Forza, C. (2012). Rapid internationalization of traditional SMEs: Between gradualist models and born globals. International Business Review, 21(4), 694-707. http://dx.doi.org/10.1016/j.ibusrev.2011.08.002

Knight, G. A., \& Cavusgil, S. T., (2004). Innovation, organizational capabilities, and the born-global firm. Journal of International Business Studies, 35(2), 124-141

Kuivalainen, O., Sundqvist, S., \& Servais, P. (2007). Firms' degree of born-globalness, international entrepreneurial orientation and export performance. Journal of World Business, 42(3), 253-267. http://dx.doi.org/10.1016/j.jwb.2007.04.010

Kuivalainen, O., Saarenketo, S., \& Puumalainen, K. (2012). Start-up patterns of internationalization: a framework and its application in the context of knowledgeintensive SMEs. European Management Journal, 30(4), 372-385. http://dx.doi.org/10.1016/j.emj.2012.01.001

Laanti, R., Gabrielsson, M., \& Gabrielsson, P. (2007). The globalization strategies of business-to-business born global firms in the wireless technology industry. Industrial Marketing Management, 36(8), 1104-1117. http://dx.doi.org/10.1016/j.indmarman.2006.10.003

Laurell, H., Andersson, S., \& Achtenhagen, L. (2013). The importance of industry context for new venture internationalisation: A case study from the life sciences. Journal of International Entrepreneurship, 11(4), 297-319. http://dx.doi.org/10.1007/s10843-013-0116-y

Lopez, L. E., Kundu, S. K., \& Ciravegna, L. (2009). Born global or born regional\&quest; Evidence from an exploratory study in the Costa Rican software industry. Journal of International Business Studies, 40(7), 1228-1238

Madsen, T. K. (2013). Early and rapidly internationalizing ventures: similarities and differences between classifications based on the original international new venture and born global literatures. Journal of International Entrepreneurship, 11(1), 65-79. http://dx.doi.org/10.1007/s10843-012-0099-0

Madsen, T. K., \& Servais, P. (1997). The internationalization of born globals: an evolutionary process? International Business Review, 6(6), 561-583. http://dx.doi.org/10.1016/S0969-5931(97)00032-2

McKinsey \& Company (1993), Emerging Exporters: Australia's High Value-Added Manufacturing Exporters. Melbourne: Australian Manufacturing Council 
Melén, S., \& Nordman, E. R., (2009). The internationalisation modes of Born Globals: A longitudinal study. European Management Journal, 27(4), 243-254. http://dx.doi.org/10.1016/j.emj.2008.11.004

Miles, M. B., \& Huberman, A. M., (2013). Qualitative data analysis: An expanded sourcebook. Sage Publications, Newbury Park

Moen, Ø., \& Servais, P. (2002). Born global or gradual global? Examining the export behavior of small and medium-sized enterprises. Journal of International Marketing, 10(3), 49-72. http://dx.doi.org/10.1509/jimk.10.3.49.19540

Nummela, N., Saarenketo, S., Jokela, P., \& Loane, S. (2014). Strategic DecisionMaking of a Born Global: A Comparative Study From Three Small Open Economies. Management International Review, 54(4), 527-50. http://dx.doi.org/10.1007/s11575-014-0211-x

Oviatt, B. M., \& McDougall, P. P. (2005). Defining international entrepreneurship and modeling the speed of internationalization. Entrepreneurship theory and practice, 29(5), 537-554. http://dx.doi.org/10.1111/j.1540-6520.2005.00097.x

Rialp, A., Rialp, J., \& Knight, G. A., (2005). The phenomenon of early internationalizing firms: what do we know after a decade (1993-2003) of scientific inquiry? International Business Review, 14(2), 147-166. http://dx.doi.org/10.1016/j.ibusrev.2004.04.006

Rialp-Criado, A., Galván-Sánchez, I., \& Suárez-Ortega, S. M. (2010). A configuration-holistic approach to born-global firms' strategy formation process. European Management Journal, 28(2), 108-123. http://dx.doi.org/10.1016/j.emj.2009.05.001

Sepulveda, F. \& Gabrielsson, M. (2013). Network development and firm growth: A resource-based study of B2B Born Globals. Industrial Marketing Management, 42(5), 792-804.

Stake, R. E. (2013). Multiple case study analysis. New York, USA: Guilford Press. http://dx.doi.org/10.1016/j.indmarman.2013.01.001

Taylor \& Jack., (2013). Understanding the pace, scale and pattern of firm internationalisation: An extension of the born global concept. International Small Business Journal, 31(6), 701-721. http://dx.doi.org/10.1177/0266242611431992

Thai, M. T. T., \& Chong, L. C., (2008). Born-global: The case of four Vietnamese SMEs. Journal of International Entrepreneurship, 6(2), 72-100. http://dx.doi.org/10.1007/s10843-008-0021-y

Trudgen, R. \& Freeman, S. (2014). Measuring the performance of born-global firms throughout their development process: The roles of initial market selection and 
internationalisation speed. Management International Review, 54(4), 551-579. http://dx.doi.org/10.1007/s11575-014-0210-y

Yin, R. K. (2009). Qualitative research from start to finish: Guilford Press. 